\title{
INNOVATIVE TECHNOLOGIES IN THE DEVELOPMENT OF ECOLOGICAL AGRICULTURE IN SOUTHERN UKRAINE
}

\author{
ІННОВАЦЙНІ ТЕХНОЛОГІЇ У РОЗВИТКУ \\ ЕКОЛОГІЧНОГО ЗЕМЛЕРОБСТВА НА ПІВДНІ УКРАЇНИ
}

\author{
Ganna G. Trokhymenko \\ antr@ukr.net \\ ORCID: 0000-0002-0835-3551 \\ Olga G. Grushyna \\ olga.bidnichenko@nuos.edu.ua \\ ORCID: 0000-0002-1209-592X \\ Oleksandr M. Marynets \\ marinets.aleks@gmail.com \\ ORCID: 0000-0002-5373-4599 \\ Olena L. Girzheva \\ olena.girzheva@nuos.edu.ua \\ ORCID: 0000-0002-6549-3278
}

\author{
Г. Г. Трохименко, \\ докт. техн. наук, професор \\ О. Г. Грушина, \\ старший викладач \\ О. М. Маринець, \\ канд. техн. наук, доцент \\ О. Л. Гіржева, \\ канд. с.-г. наук, доцент
}

Admiral Makarov National University of Shipbuilding, Mykolaiv

Національний університет кораблебудування імені адмірала Макарова, м. Миколаїв

\begin{abstract}
The paper identifies the feasibility of using computer simulations of the irrigation process for growing crops in the steppe in Southern Ukraine in order to obtain better yields, calculations of irrigation and determination of irrigation rates, as well as general water supply of crops. The analysis of the structural features and principles of work of modern automated decision-making systems intended for the decision of problems of diverse agricultural tasks is resulted. The following systems are considered: 1. CROPWAT program, which is a decision support tool that allows you to perform standard calculations for evapotranspiration and study the use of irrigation systems, as well as to create irrigation schemes and their management. 2. The system "Irrigation online" is a hardware and software tool that introduces innovative technologies of professional irrigation and implements automatic irrigation systems from design to harvest. 3. The Agricultural Production Systems Simulator (APSIM). The simulator of agricultural production systems is a modular platform for modelling biophysical processes in agricultural systems. Especially in such systems that relate to the economic and environmental performance of climate risk management practices; 4. Particular attention is paid to the AquaCrop program, which is a model of productivity of the system "crop - humidification", designed to assess the impact of environmental conditions and management on crop productivity. The system predicts the yield of herbaceous plants depending on water consumption, which is especially important in conditions where moisture deficiency is the main factor that limits crop productivity. The work of the AquaCrop program on the example of modelling the growing season and calculation of potato yield is considered. Four stages of final crop modelling are analyzed, the corresponding algorithms of parameter calculations are given. Systematized and divided into blocks for each parameter data required to calculate the simulation of the growing season. Quantities such as the amount of evaporated moisture, the possible number of weeds, the salinity of the soil, the inflow of rain moisture, the amount of moisture in each growing season, the salinity of the soil in the section, the balance of moisture and evaporation were calculated. The results of calculations are given in the form of graphs-diagrams. The end result of the program is a simulated yield index and the number of possible harvests that is presented in the paper.
\end{abstract}

Key words: ecological farming; decision support system; irrigation; yield; irrigation rate; water supply.

Анотація. У роботі визначено доцільність використання засобів комп'ютерного моделювання процесу зрошення для вирощування сільськогосподарських культур в умовах Степу на Півдні України з метою отримання кращих урожаїв, приведено розрахунки зрошення та визначення норм поливу, а також загального водопостачання сільськогосподарських культур. Наведено аналіз особливостей будови та принципів роботи 
сучасних автоматизованих систем прийняття рішень, що призначені для розв'язання проблем різнопланових сільськогосподарських задач. Розглянуто такі системи: 1. Програма CROPWAT, що є інструментом підтримки прийняття рішень, який дозволяє проводити стандартні обчислення для евапотранспірації й вивчення використання поливних систем, а також для створення зрошувальних схем і управління ними. 2. Система «Полив онлайн»є апаратно-програмним інструментом, який запроваджує інноваційні технології професійного зрошення та реалізує автоматичні системи поливу від проєкту до збору урожаю. 3. The Agricultural Production Systems Simulator (APSIM). Симулятор систем сільськогосподарського виробництва - це модульна платформа для моделювання біофізичних процесів у сільськогосподарських системах. Особливо в таких системах, що стосуються економічних та екологічних результатів практики управління в умовах кліматичного ризику. 4. Особливу увагу приділено програмі AquaCrop, яка є моделлю продуктивності системи «сільгоспкультура - зволоження», що розроблена для оцінки впливу умов навколишнього середовища та управління на продуктивність сільськогосподарських культур. Система прогнозує врожайність трав’янистих рослин залежно від водоспоживання, що особливо актуально в умовах, коли дефіцит вологи є головним чинником, який лімітує продуктивність культур. Розглянуто роботу програми AquaCrop на прикладі моделювання періоду вегетації та розрахунку врожайності картоплі. Проаналізовані чотири етапи моделювання кінцевого урожаю, наведено відповідні алгоритми розрахунків параметрів. Систематизовані та розділені по блоках для кожного параметра дані, необхідні для розрахунку симуляції періоду вегетації. Прораховано такі величини, як кількість випаруваної вологи, можлива кількість бур'янів, засоленість грунту, надходження дощової вологи, кількість вологи на кожному періоді вегетації, солоність грунту у розрізі, баланс вологи й випаровування. Результати розрахунків наведено у вигляді графіків-діаграм. Кінцевим результатом роботи програми є змодельований індекс урожаю та кількість можливого врожаю, які представлено у роботі.

Ключові слова: екологічне землеробство; система підтримки прийняття рішення; зрошення; урожайність; поливна норма; водопостачання.

\section{ПОСТАНОВКА ЗАДАЧІ}

Завдання - провести розрахунки параметрів вологи, якості грунту, характеристики водно-соляного балансу, а також індекс урожаю та прогнозовану величину врожаю під час вирощування сільськогосподарських культур на прикладі вирощування картоплі.

\section{АНАЛІЗ ОСТАННІХ ДОСЛІДЖЕНЬ І ПУБЛІКАЦІЙ}

За оцінками ФАО, агроресурсний потенціал України використовуються не більше ніж на третину [1]. Недостатній рівень використання наявного агроресурсного потенціалу обмежується цілою низкою чинників, головним із яких $\epsilon$ неоптимальні умови природного вологозабезпечення на більш ніж 2/3 території України, які постійно погіршуються внаслідок глобальних змін клімату [2]. Тому в умовах Степу на Півдні України ефективне землеробство без зрошення стало практично неможливим [3; 4]. Застосування зрошення та дренажу дозволяє незалежно від погодних умов підвищити врожайність сільськогосподарських культур в 2-3 рази порівняно з богарними умовами.

У зв'язку з цим в Україні прийнято Стратегію зрошення та дренажу на період до 2030 року [5], в якій визначені стратегічні напрями державної політики щодо зрошення та дренажу, забезпечення сталого екозбалансованого розвитку землеробства в Україні, зокрема екологізації сільськогосподарського виробництва. Передбачено нарощення потенціалу зрошення, модернізацію наявних та будівництво нових зрошувальних систем. Розвиток систем зрошення сприятиме збереженню та відтворенню родючості грунтів України.

\section{META CTATTI}

Метою є впровадження інноваційних технологій екологічного землеробства на основі аналізу розрахунку зрошення та визначення норм поливу сільськогосподарських культур; визначення особливостей будови та принципів роботи сучасних автоматизованих систем прийняття рішень, що призначені для розв'язання проблем різнопланових сільськогосподарських задач; отримання прогнозованої величини врожаю для визначених кліматичних умов.

\section{ОСНОВНИЙ МАТЕРІАЛ}

Одним із заходів щодо реалізації Стратегії зрошення та дренажу [5] є впровадження систем нормування поливу рослин. Норма поливу залежить від глибини кореневого шару грунту, що підлягає зволоженню, особливостей культури і фази ії розвитку, а також від механічного складу і водно-фізичних властивостей грунту, способу і призначення поливу та ін. Зазвичай у самопливних вегетаційних поливах поливні норми становлять 600-1200 м³/га, за дощування - 300-800 м³/га, за вологозарядкових поливів 1000-2000 м $3 /$ га.Зрошувальнанорма,якупотрібноподати за весь період вегетації, $M$ визначається за виразом: $M=E-10 \mu$ Hос $-\left(\mathrm{W}_{\mathrm{H}}-\mathrm{W}_{\mathrm{K}}\right)-\mathrm{W}_{\Gamma}, \mathrm{M}^{3} /$ га, де: $E$ - загальне водоспоживання культури, м³/га; $\mathrm{H}_{\text {ос }}$ - кількість опадів, що випали за вегетаційний період такої культури, мм; $\mu$ - коефіцієнт використання опадів; $\mathrm{W}_{\text {н }}$ - запас вологи в розрахунковому шарі грунту на початку вегетаційного періоду, м³/га; 


\section{ТЕХНОЛОГІЇ ЗАХИСТУ НАВКОЛИШНЬОГО СЕРЕДОВИЩА № 1-2021}

$\mathrm{W}_{\text {к }}$ - те ж наприкінці вегетаційного періоду, $\mathrm{M}^{3} /$ га; $\mathrm{W}_{\text {г }}$ - кількість води, що надходить у розрахунковий шар грунту по капілярах від грунтових вод за вегетаційний період, м $^{3} /$ га [6].

Своєю чергою загальне водоспоживання культури $E$ визначається: $\mathrm{E}=\mathrm{У} \times \mathrm{K}_{\mathrm{B}}$, де: $\mathrm{У}$ - запланований урожай культури, т/га; $\mathrm{K}_{\mathrm{B}}$, - коефіцієнт водоспоживання, $\mathrm{M}^{3} / \mathrm{T}$; $\mathrm{K}_{\mathrm{в}}$ - це відношення сумарної витрати вологи (тобто витрата на випаровування 3 грунту плюс транспірація) в м³/га до врожаю основної продукції в т/га.

Оскільки потреба рослин у воді протягом вегетаційного періоду неоднакова і частково задовольняється опадами, що випадають, зрошувальну норму слід подавати в посушливі періоди на поле не відразу, а частинами. Кількість води, яку необхідно подати на 1 га за один полив, називається поливною нормою $\mathrm{m}$ і визначається за формулою: $m=100 h d\left(\beta_{\max },-\beta_{\min }, \mathrm{M}^{3} /\right.$ га, де: $\mathrm{h}$ - глибина активного шару грунту, м; $\mathrm{d}$ - об'ємна маса розрахункового шару грунту, т/ $\mathrm{M}^{3} ; \beta_{\max }-$ вологість у \% до маси сухого грунту; $\beta_{\min }-$ вологість у $\%$ до маси сухого грунту, що відповідна нижній межі зволоження, тобто $\beta_{\min }=(0,6 / 0,8) \beta_{\max }$. Поливні норми (табл. 1$)$ і терміни поливу сільськогосподарських культур визначаються графоаналітичним способом [7], який було розроблено академіком А.Н. Костяковим.

Таблиця 1. Норми поливу картоплі на один гектар

\begin{tabular}{|c|c|c|}
\hline \multirow{2}{*}{ Сорт картоплі } & \multicolumn{2}{|c|}{ Норма поливу, $\mathbf{m}^{\mathbf{3}} / \mathbf{\Gamma a}$} \\
\cline { 2 - 3 } & $\mathbf{m i n}$ & $\mathbf{m a x}$ \\
\hline Ранньостиглий & 55 & 75 \\
\hline Середньостиглий & 65 & 90 \\
\hline Пізньостиглий & 85 & 110 \\
\hline
\end{tabular}

Протягом вегетаційного періоду зрошувальну норму подають частинами відповідно до зміни потужності кореневого шару, потреби рослин у воді, природним зволоженням, допустимими межами вологості. Точність дотримання необхідного режиму вологості залежить від частоти та дозування поливу. Чим частіше і менше за значенням поливи, тим точніше може бути витриманий необхідний режим вологості в розрахунковому шарі, але при цьому зростають технічні й організаційні труднощі та економічні витрати. Безперервна подача води, яка узгоджена з режимом зрошення, можлива тільки на автоматизованих системах крапельного і підгрунтового зрошення.

Як свідчить вітчизняний та світовий досвід, нині для управління зрошенням усе частіше використовуються автоматизовані системи підтримки прийняття рішень (СППР), які є інструментами для управління технологічними процесами поливу на основі визначення строків та норм поливу з урахуванням дефіциту вологозабезпечення відповідно до основних фаз розвитку сільськогосподарських культур [5].

Розглянемо детальніше деякі з відомих сучасних систем підтримки прийняття рішень у сільськогос- подарському виробництві, які підвищують рівень автоматизації та екологізації сільськогосподарського виробництва.

$C R O P W A T$ - це інструмент підтримки прийняття рішень, розроблений Відділом земельних та водних ресурсів ФАО. Це практичний інструмент, створений для агро-метеорологів, агрономів і інженерів систем зрошення, який дозволяє виробляти стандартні обчислення для евапотранспірації й вивчення використання поливних систем, а також для створення зрошувальних схем і управління ними [8]. Програма проводить розрахунки потреби сільськогосподарських культур у воді та іригаційних даних на базі даних про грунт, клімат та врожай. Крім того, програма дозволяє розробляти графіки зрошення та розраховувати схеми водопостачання для різних сільськогосподарських культур.

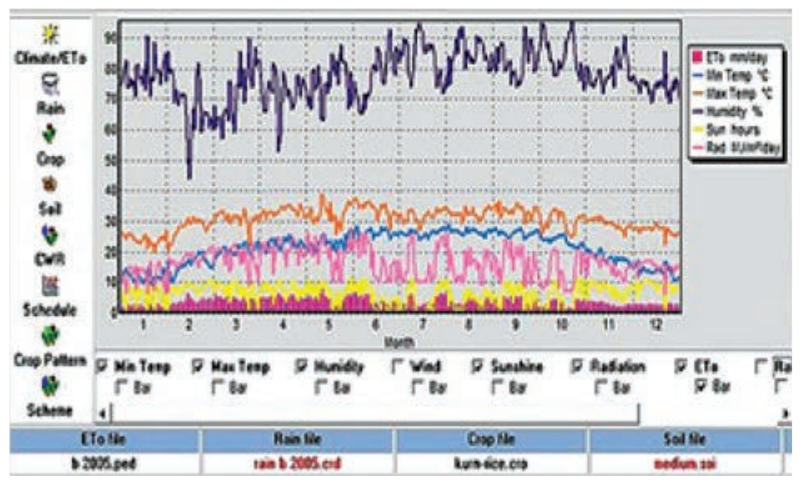

Рис. 1. Графік розподілу параметрів повітря протягом року

Програма CROPWAT містить стандартні дані про культури та стан грунту, які можуть бути використані як перше наближення у разі відсутності конкретних даних. У разі доступності локальних даних файли легко змінити. Як недоступність кліматичних даних можна отримати інформацію із метеостанцій по всьомy світу із програми CLIMWAT, яка безпосередньо зв'язана $з$ кліматичною базою даних. На рис. 1 показано графік, що відображає розподіл параметрів повітря - сонячні години, мінімальну та максимальну температуру, вологість, радіацію та еталонну евапотранспірацію протягом року, що використовуються у розрахунках норм зрошення. Розробка графіків поливу в програмі базується на щоденному балансі грунту та води 3 використанням різних опцій користувача для умов водопостачання та управління поливом. Схема подачі води розраховується у відповідності до схеми посівів, яка задається користувачем, та може містити до 20 культур.

Система «Полив онлайн» $є$ апаратно-програмним інструментом, який запроваджує інноваційні технології професійного зрошення та реалізує автоматичні системи поливу від проєкту до збору урожаю. Крім того, дозволяє зменшити трудомісткі та енергозатратні процеси, пов'язані з поливом та збоями у системі. 
Метою використання системи є забезпечення високої врожайності культур за оптимальної норми зрошення та «розумному», тобто агрономічно та екологічно обгрунтованому, дозуванні добрив.

Загалом система «Полив онлайн» складається 3 апаратної частини, розміщеної у полі, та програмної частини, що містить бази даних, підсистем моделювання та користувацького інтерфейсу (рис. 2).

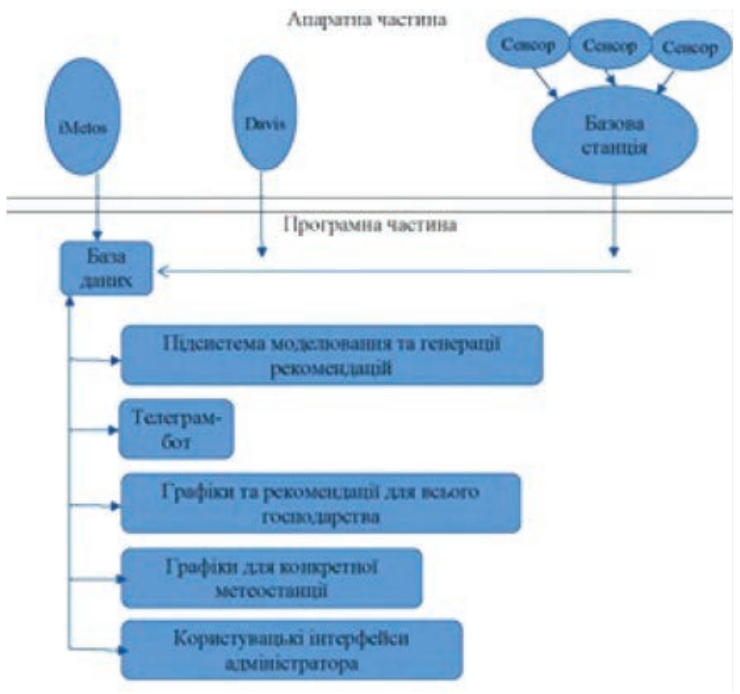

Рис. 2. Структура системи «Полив онлайн»

Як апаратна частина у системі метеостанції iMetos чи Davis, а також як обладнання власної розробки, система моніторингу метеорологічних показників та стану вологозабезпечення грунту складається з базових станцій та віддалених вузлів iз сенсорами. Для моніторингу стану вологозабезпечення і доступності грунтової вологи для рослин [9] використовують сенсори Watermark та тензіометри власної розробки. Кожен сенсор оснащений системою безпровідної передачі даних на базову станцію та незалежним живленням із сонячною батареєю. Базова станція, збираючи дані із сенсорів, відправляє їх $G P R S$-каналом на сервер, де вони проходять пост обробку, зокрема в контексті автоматичного виявлення некоректних даних і потенційної несправності сенсорів, та зберігаються у базі даних системи на погодинній основі.

The Agricultural Production Systems Simulator (APSIM) - Симулятор систем сільськогосподарського виробництва [10], що розроблений Відділом досліджень систем сільськогосподарського виробництва у Австралії, - це модульна платформа для моделювання біофізичних процесів у сільськогосподарських системах, особливо тих, що стосуються економічних та екологічних результатів практики управління в умовах кліматичного ризику. APSIM є складною модульною структурою, що складається 3 численних окремих модулів рослин, грунтів та управління (рис. 3).

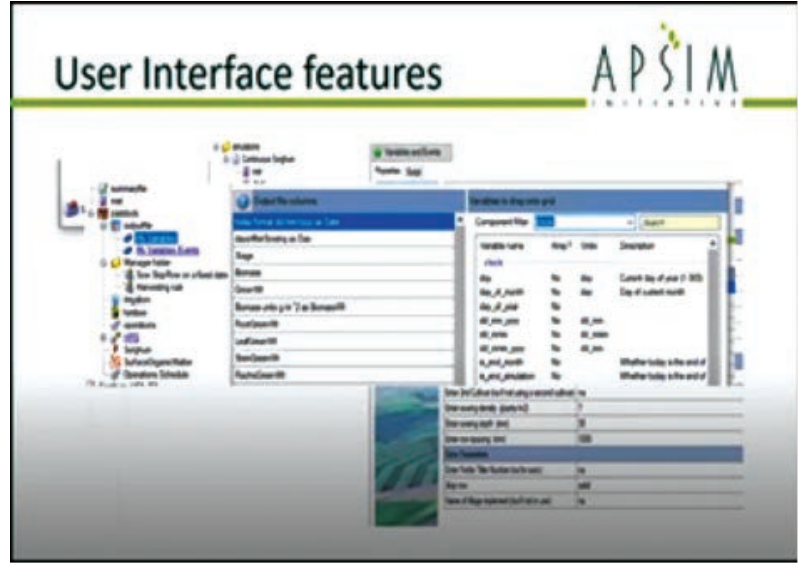

Рис. 3. Інтерфейс системи APSIM

Вони містять у собі різноманітний спектр сільськогосподарських культур, пасовищ та дерев, грунтові процеси, включаючи водний баланс, перетворення азоту $N$ та фосфору $P, p H$ і ерозію грунту, а також гнучкий спектр управлінського контролю.

APSIM - одна із таких складних моделей, яка продовжує розвиватися вже багато років та всі різнопланові додатки адаптуються до цієї складної дослідної програми. Модулі програми містять підтримку прийняття рішень на фермі, оцінку цінності сезонного прогнозування клімату, розробку головних принципів керування відходами тощо, а також використовується як керівництво у дослідницькій та освітній діяльності.

Інша система прийняття рішень AquaCrop - це модель продуктивності системи «сільгоспкультура-зволоження» [11], яка розроблена Відділом земельних і водних ресурсів ФАО для забезпечення продовольчої безпеки і оцінки впливу умов навколишнього середовища та управління на продуктивність культур. AquaCrop прогнозує врожайність трав'янистих рослин залежно від водоспоживання, що особливо актуально в умовах, коли дефіцит вологи є головним чинником, який лімітує продуктивність культур. Система AquaCrop поєднує у собі точність, простоту та надійність. У цій моделі використовується невелика кількість параметрів та початкових змінних, які інтуїтивно зрозумілі та легко визначаються користувачем, що гарантує широке коло використання програми.

У наших дослідженнях застосовано програму AquaCrop [12] з метою аналізу можливості вирощування картоплі та культури, яка не $є$ традиційною для Півдня України, та у разі обгрунтованого наукового підходу це стає реальним та екологічно вигідним сільськогосподарським виробництвом.

Розглянемо роботу програми AquaCrop на прикладі моделювання періоду вегетації та розрахунку врожайності картоплі.

AquaCrop моделює кінцевий урожай у чотири етапи:

1. Розвиток зеленого покривного покриву. В AquaCrop розвиток листя виражається через зелений покрив (canopy cover CC), а не через індекс площі листя, як у інших програмах. Щодня відстежуючи 


\section{ТЕХНОЛОГІЇ ЗАХИСТУ НАВКОЛИШНЬОГО СЕРЕДОВИЩА № 1-2021}

вміст води в грунтовому профілі, програма відстежує навантаження, які виникають у кореневій зоні. Тиск грунту і води може вплинути на ріст листя та розширення крони; що може викликати передчасне старіння полога.

2. Транспірація сільськогосподарських культур. В умовах гарного поливу транспірація сільськогосподарських культур $\left(T_{r}\right)$ розраховується шляхом множення еталонного сумарного випаровування $\left(E T_{\text {o }}\right)$ на коефіцієнт культури $(\mathrm{KcTr})$. Коефіцієнт культури пропорційний зеленому покриву $(C C)$, отже, змінюється протягом життєвого циклу культури відповідно до модельованого на основі проєктивного покриття рослин. Водний стрес може не тільки вплинути на розвиток рослинного покриву, він також може викликати закриття продихів і тим самим безпосередньо вплинути на транспірацію сільськогосподарських культур.

3. Надземна біомаса. Кількість виробленої надземної біомаси $(B)$ пропорційна сукупній кількості транспірації сільськогосподарських культур ( $\Sigma T r)$ та коефіцієнту корисності води біомаси $(W P)$ :

$$
B=W P \times \Sigma T r
$$

де $B$ - біомаса врожаю; $W P$ - пропорційний коефіцієнт корисності води біомаси; $\Sigma T r$ - транспірація сільськогосподарських культур.

В AquaCrop коефіцієнт WP нормалізований з урахуванням кліматичних умов, що створює нормовану продуктивність води біомаси $\left(W P^{*}\right)$ дійсною для різних місць, сезонів і концентрацій вуглекислого газу.

4. Урожайність сільськогосподарських культур. Змодельована надземна біомаса об’єднує всі продукти фотосинтезу, що засвоєні культурою протягом сезону. Урожайність $(Y)$ виходить із кількості біомаси $(B) 3$ використанням індексу врожаю $(H I)$, який являє собою частку кількості продуктивної біомаси (В). Фактичний індекс НI розраховується під час моделювання шляхом ітераційного коригування контрольного індексу збору врожаю (HIо) з урахуванням поправочних коефіцієнтів для впливу тиску.

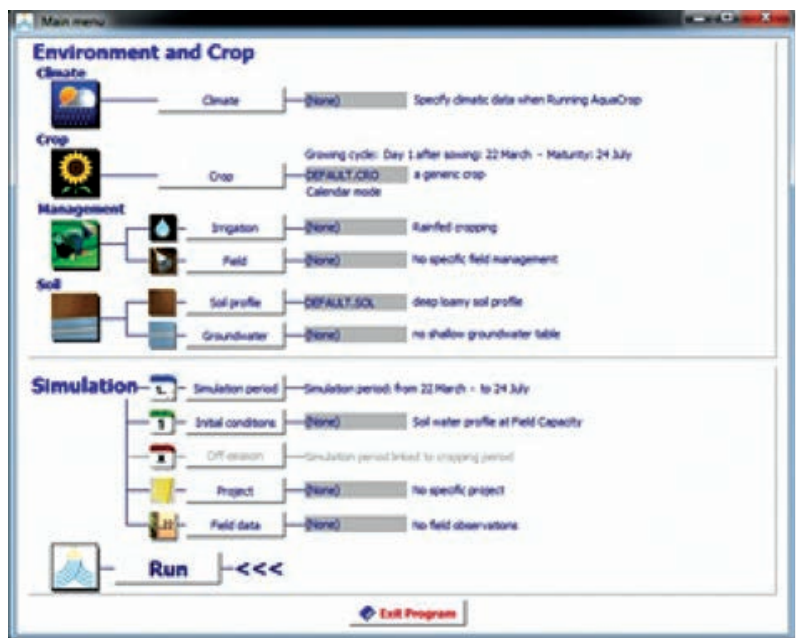

Рис. 4. Вікно для внесення даних програми AquaCrop

$$
\left(\frac{Y_{x}-Y_{a}}{Y_{x}}\right)=K_{y}\left(\frac{E T_{x}-E T}{E T_{x}}\right)
$$

$Y_{x}$ - урожайність картоплі; $Y_{a}$ - посадочний матеріал; $E T_{x}$ - сумарне випаровування протягом періоду вегетації.

Теоретичні основи, що викладені вище, закладено в алгоритм роботи програми, початкові дані для якої вводяться у графічне вікно системи (рис. 4).

Дані, що необхідні для симуляції періоду вегетації, систематизовані та подані нижче у табл. 2 і розділені за блоками для кожного параметру.

Проводячи розрахунки за цією програмою, отримано значення достатньої кількості показників, які дозволили зробити рекомендації щодо оптимального шляху вирощування картоплі відповідно до початкових даних.

\begin{tabular}{|c|c|c|c|c|}
\hline Група даних & Показник & $\begin{array}{c}\text { Назва } \\
\text { параметру }\end{array}$ & Детальний опис & $\begin{array}{c}\text { Шлях } \\
\text { отримання }\end{array}$ \\
\hline \multirow{9}{*}{$\begin{array}{c}\text { Навколишнє } \\
\text { середовище } \\
\text { та врожай }\end{array}$} & \multirow{4}{*}{ Клімат } & $\begin{array}{c}\text { Кількість } \\
\text { опадів }\end{array}$ & $\begin{array}{c}\text { Кількість опадів кожного дня } \\
\text { у період вегетації }\end{array}$ & {$[13]$} \\
\hline & & Евапотран-спірація & Випаровування з грунту & Дані з програми \\
\hline & & Температура & Температура кожного дня у період вегетації & {$[13]$} \\
\hline & & Вміст $\mathrm{CO}_{2}$ & Кількість $\mathrm{CO}_{2}$ у повітрі & Дані з програми \\
\hline & Врожай & Родючість & Сорт картоплі для певного типу грунту & Дані з програми \\
\hline & \multirow{2}{*}{ Догляд } & Полив & Кількість та вид поливу & {$[15 ; 17]$} \\
\hline & & Добрива & Вид внесення добрив & {$[16 ; 15]$} \\
\hline & \multirow{2}{*}{ Грунт } & Вид грунту & Карта грунтів & [14] \\
\hline & & Підземні води & Розташування відносно поверхні & Дані з програми \\
\hline \multirow{2}{*}{$\begin{array}{c}\text { Симуляція } \\
\text { вирощування }\end{array}$} & $\begin{array}{c}\text { Період } \\
\text { вегетації }\end{array}$ & Період росту & Стадія дозрівання об’єкта дослідження & {$[18]$} \\
\hline & $\begin{array}{c}\text { Початкові } \\
\text { умови грунту }\end{array}$ & $\begin{array}{l}\text { Початковий стан і } \\
\text { вологість грунту }\end{array}$ & Методом дослідження & \\
\hline
\end{tabular}

Таблиця 2. Перелік даних, необхідних для запуску моделі з оцінки урожайності 


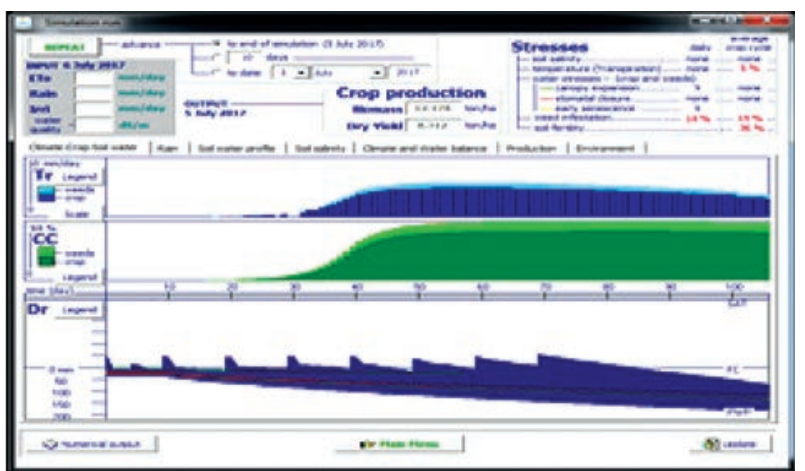

Рис. 5. Кількість паростків бур'янів відносно до врожаю (CC), їх транспірація (Tr) та глибина зони коріння (Dr)

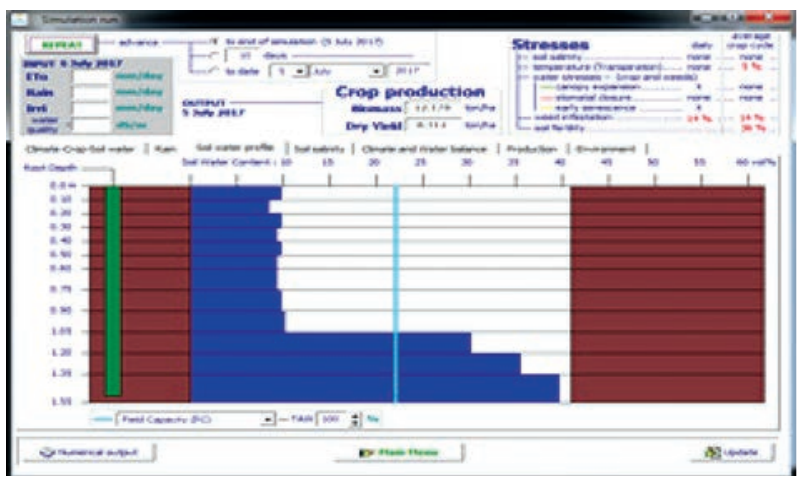

Рис. 7. Відсоток вологості грунту (Soil water Content) на певній глибині (Root Depth)

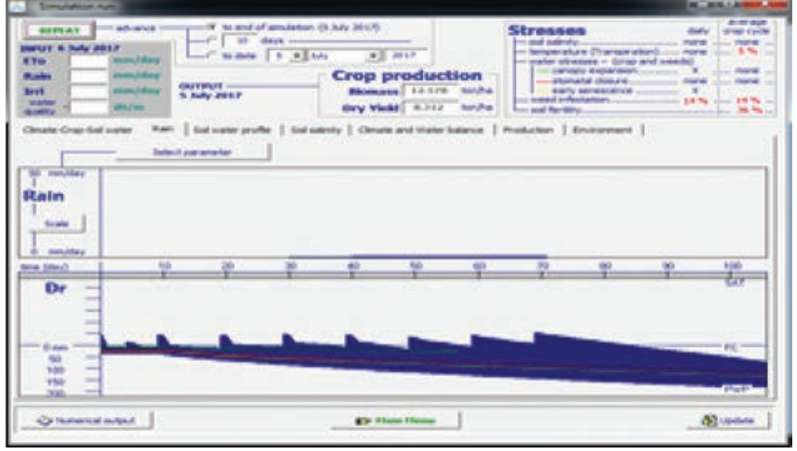

Рис. 6. Кількість опадів за період вегетації (Rain)

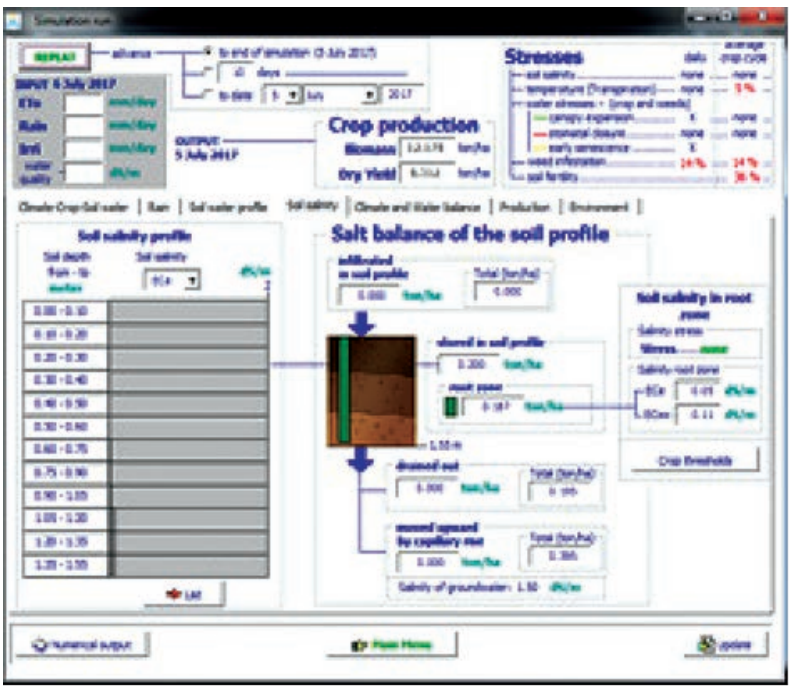

Рис. 8. Рівень засолення грунту (Soil salinity profile)

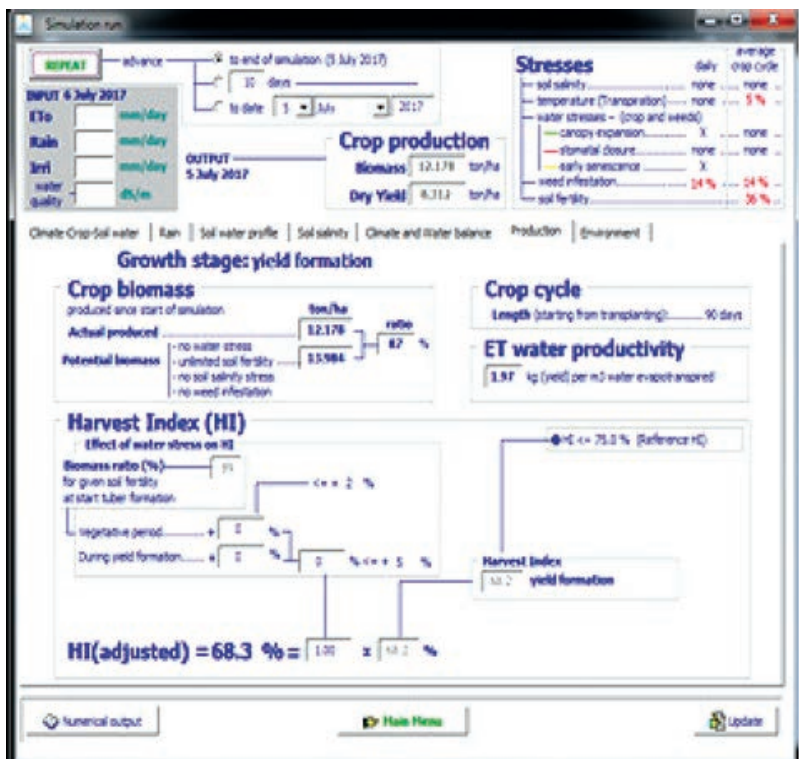

Рис. 10. Змодельований індекс урожаю (НI) та кількість можливого врожаю (Potential biomass) 


\section{ТЕХНОЛОГІЇ ЗАХИСТУ НАВКОЛИШНЬОГО СЕРЕДОВИЩА № 1 2021}

Під час застосування цієї програми на практиці було прораховано такі величини, як кількість випаруваної вологи, можлива кількість бур'янів, засоленість грунту, надходження дощової вологи, кількість вологи на кожному періоді вегетації, солоність грунту у розрізі, баланс вологи й випаровування, а також можливу кількість отримання врожаю. Саме ці параметри вкрай необхідні фермерам для визначення технології вирощування сільськогосподарських культур, зокрема картоплі.

Отримані результати розрахунків наведені у вигляді графіків-діаграм, що зображені на рис. 5-10.

Отже, після виконання цих наведених розрахунків можна визначити оптимальну схему виробничого циклу вирощування культури для кожного району відповідно до його вихідних даних.

Проводячи розрахунки в програмі AquaCrop, отримали значення достатньої кількості показників, які дозволили зробити висновки щодо оптимального шляху вирощування картоплі відповідно до початкових даних, що робить процес вирощування автоматизованим та екологічним.

\section{ВИСНОВКИ}

Описані у статті системи підтримки прийняття рішень дають можливість користувачам використовувати інноваційні наукові підходи до вирощування сільськогосподарських культур та організувати процес вирощування на сучасному технологічному рівні. Такі системи $є$ інструментами, мета яких - сприяння отриманню найвищих урожаїв.

Застосування програми AquaCrop дало можливість авторам оцінити потенційний врожай за різних природно-кліматичних і технологічних умов з урахуванням потенційних ризиків та на основі моделювання продуктивності надати рекомендації щодо підвищення ефективності вирощування культури та розвитку екологічного землеробства в такому регіоні.

\section{REFERENCES}

[1] Poiasniuvalna zapyska do proektu Zakonu Ukrainy "Pro vnezennia zmin do Podankovogo kodeksu Ukrainy stchodo derzhavnoi pidtrymky siskogozpodarskykh tovarovyrobnykiv" vid 27.05.2020 No. 3548. Data rozgliadannia: 26.05.2020. [in Ukrainian].

[2] The Climate Change Performance Index Results 2016. Retrieved from: https://necu.org.ua/climate/.

[3] V Ukraini vse bilshe regioniv, de bez zroshennia agrobiznes nemozhlyvyi. Retrieved from: http://uga.ua/meanings/vukrayini-vse-bilshe-regioniv-de-bez-zroshennya-agrobiznes-nemozhlivij/ [in Ukrainian].

[4] Lozovitskiy P.S. Naukovi osnovy upravlinnia ekologochnoiu bezpekoiu zroshuvanykh zemel pivdnia Ukrainy: Dusertatsiia na zdobuttia naukovogo stupenia doctora tekhnichnykh nauk. Kyiv, 2015. Retrieved from: http://dea.edu.ua/img/source/Doc/ disLozov.pdf [in Ukrainian].

[5] Strategiia zroshennia ta drenashu v Ukraini na period do 2030 roku. Skhvaleno rozporiadzhenniam Kabinetu Ministriv Ukrainu vid 14.08.2019 r. No. 688-p. [in Ukrainian].

[6] Rezhum zroshennia i tekhnica polivu silskogospodarskukh kulnur. Retrieved from: https://studfile.net/preview/5198028/ [in Ukrainian].

[7] Kostiakov, A. N. (1960). Osnovu melioratsui. Moskva: Selkhozgiz. 622 s. [in Russian].

[8] CropWat. Retrieved from: https://www.linguee.com/englishrussian/translation/crop+calendar.html/.

[9] Datchiky vologosti gruntu irrometer Company Inc. irrometer.com Retrieved from: https://www.irrometer.com/sensors.html.

[10] Apsim. Retrieved from: https://www.researchgate.net/publication/263238329_The_APSIM_Model_-_An_Overview.

[11] Steduto, P., Hsiao, T. C., Fereres, E., (2009). AquaCrop - the FAO crop model to simulate yield response to water: I. Concepts and underlying principles. Agron. J. 101, P. 426-437.

[12] АкvaKrop (AquaCrop). URL: Retrieved from: http://www.fao.org/aquacrop/ru/

[13] Apkhiv pogody v Nikolaeve, (aeroport), METAR. URL: Retrieved from: https://rp5.ua/Архив_погоды_в_Николаеве_ (аэропорт),_METAR [in Russian].

[14] Karta gruntiv Ukrainy. Retrieved from: https://superagronom.com/karty/karta-gruntiv-ukrainy [in Russian].

[15] Hrushetskiy, S. (2015). Analiz suchasnykh tekhnologii vyroschyvannia I zbyrannia kertopli [The evaluation of modern technology in growing and harvesting the potatoes]. Zbirnyk naukovykh prats Podilskogo derzhavnogo agrarno-tekhnichnogo universytetu. Tekhnichni nauky. Vyp. 24(2). Pp. 55-64.

[16] Dobruva vid shkidnykiv dlia kartopli. Retrieved from: http://potatoclub.com.ua/news.

[17] Kartopliarstvo: osoblyvosti tekhniky i tekhnologii. Retrieved from: http://agro-business.com.ua.

[18] Bolotskikh, A. (2002). Kartophel [Potatoes] Kharkov: Folio. ISBN 966-03-1367-5 [in Russian].

[19] Bolotskikh, A. Enciclopediya ovochivnyka. Kharkov: Folio, 2005. 798 s. ISBN 966-03-2716-1 [in Ukrainian].

\section{СПИСОК ВИКОРИСТАНОЇ ЛІТЕРАТУРИ}

[1] Пояснювальна записка до проєкту Закону України «Про внесення змін до Податкового кодексу України щодо державної підтримки сільськогосподарських товаровиробників» від 27.05.2020 № 3548. Дата розглядання: 26.05.2020.

[2] The Climate Change Performance Index Results 2016. URL: https://necu.org.ua/climate.

[3] В Україні все більше регіонів, де без зрошення агробізнес неможливий. URL: http://uga.ua/meanings/v-ukrayinivse-bilshe-regioniv-de-bez-zroshennya-agrobiznes-nemozhlivij/. 
[4] Лозовіцький, П. С. (2015) Наукові основи управління екологічною безпекою зрошуваних земель Півдня України : дисертація на здобуття наукового ступеня доктора технічних наук. Київ, 2015. URL: http://dea.edu.ua/img/source/Doc/ disLozov.pdf.

[5] Стратегія зрошення та дренажу в Україні на період до 2030 року. Схвалено розпорядженням Кабінету Міністрів України від 14.08.2019 р. № 688-р.

[6] Режим зрошення і техніка поливу сільськогосподарських культур. URL: https://studfile.net/preview/5198028/.

[7] Костяков, А. Н. (1960) Основы мелиорации. Москва : Сельхозгиз, 622 с.

[8] CropWat. URL: https://www.linguee.com/englishrussian/translation/crop+calendar.html (дата звернення: 11.12.2020).

[9] Датчики вологості грунту irrometer Company Inc. URL: https://www.irrometer.com/sensors.html (дата звернення: 11.12.2020).

[10] Apsim. URL: https://www.researchgate.net/publication/263238329 The APSIM Model - An_Overview (дата звернення: 11.12.2020).

[11] Steduto, P., Hsiao, T. C., Fereres, E. (2009) AquaCrop - the FAO crop model to simulate yield response to water: I. Concepts and underlying principles. Agron. J. 101, P. 426-437.

[12] АкваКроп (AquaCrop). URL: http://www.fao.org/aquacrop/ru/ (дата звернення: 13.12.2020).

[13] Архив погоды в Николаеве, (аэропорт), METAR. URL: https://rp5.ua/Архив_погоды_в_Николаеве_(аэропорт), METAR (дата звернення: 7.12.2020).

[14] Карта грунтів України. URL: https://superagronom.com/karty/karta-gruntiv-ukrainy (дата звернення: 9.12.2020).

[15] Грушецький, С. М. (2016) Аналіз сучасних технологій вирощування і збирання картоплі. Збірник наукових праць Подільського державного аграрно-технічного університету. Технічні науки. 2016. Вип. 24(2). С. 55-64. URL: http://nbuv.gov.ua/UJRN/ZnpPdatut_2016_24\%282\%29_10.

[16] Добрива від шкідників для картоплі. URL: http://potatoclub.com.ua/news (дата звернення: 10.06.2019).

[17] Картоплярство: особливості техніки і технологіï. URL: http://agro-business.com.ua (дата звернення: 20.10.2020).

[18] Болотских, А. С. (2002) Картофель. Харьков : Фолио, 254 с.: ил. (Домашняя библиотека). ISBN 966-03-1367-5.

[19] Болотских, А. С. (2005) Энциклопедия овощевода. Харьков : Фолио, 798 с.

(C) Трохименко Г. Г., Грушина О. Г., Маринець О. М., Гіржева О. Л. Дата надходження статті до редакції: 10.03.2021 Дата затвердження статті до друку: 24.03.2021 